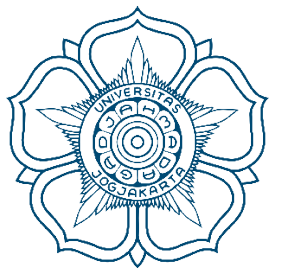

Tittle

: STATE-OWNED ENTERPRISE AND PUBLIC SERVICE OBLIGATION IN THE SECTOR OF OIL AND GAS

Author : : Muhammad Insa Ansari

MIMBAR HUKUM

DOI : : http://doi.org/10.22146/jmh.23643

Publisher : Faculty of Law Universitas Gadjah Mada

URL : jurnal.ugm.ac.id/jmh

E Issn : : 2443-0994

P Issn : :0852-100x 


\title{
STATE-OWNED ENTERPRISE AND PUBLIC SERVICE OBLIGATION IN THE SECTOR OF OIL AND GAS*
}

\author{
Muhammad Insa Ansari** \\ Private Law Department \\ Faculty of Law, University of Syiah Kuala \\ Jalan Putro Phang No. 1 Darussalam, Banda Aceh, Aceh 23111
}

\begin{abstract}
The 1945 Constitution of the Republic of Indonesia regulates natural recources in its particular article. Then, the Energy Law and the Oil and Gas Law regulate the state's control of oil and natural gas. In the sectoral regulations of oil and gas, there is a public service obligation (PSO) which must be assumed by the Government and State Owned Enterprises (SOE). Meanwhile, in the SOE Law introduced entity Perum and Persero. Where in Perum entities carrying out public service, while the Persero entity to assume the role for profit. But in practice found a PSO on the oil and gas sector carried by state-run entities Persero.
\end{abstract} Keywords: state enterprise, PSO, oil and gas.

\section{Intisari}

Dalam Undang-Undang Dasar Negara Republik Indonesia 1945 diatur penguasaan negara terhadap sumber daya alam. Kemudian UU Enegi dan UU Minyak dan Gas Bumi mengatur penguasaan negara terhadap minyak dan gas bumi. Dalam pengaturan sektoral di bidang tersebut juga mengatur kewajiban pelayanan umum yang harus diemban oleh pemerintah dan BUMN. Sementara itu dalam UU BUMN diperkenalkan entitas Perusahaan Umum (Perum) dan Perseroan Terbatas (Persero). Dimana entitas Perum mengemban peran pelayanan umum (public service), sementara entitas Persero mengemban peran mencari keuntungan (profit oriented). Namun dalam praktek ditemukan kewajiban pelayanan umum pada sektor minyak dan gas bumi diemban oleh BUMN dengan entitas Persero.

Kata Kunci: BUMN, kewajiban pelayanan umum, minyak dan gas bumi.

\section{Pokok Muatan}

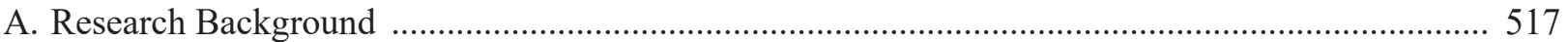

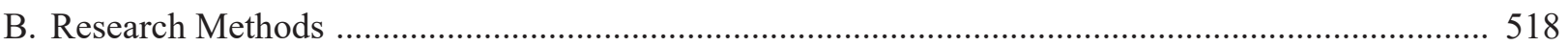

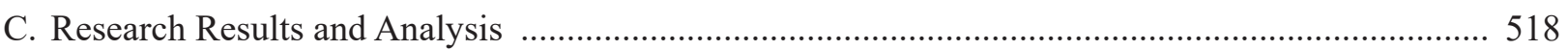

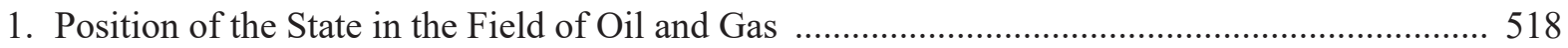

2. Public Service Obligation in the Sector of Oil and Gas by State-Owned Enterprise ................. 522

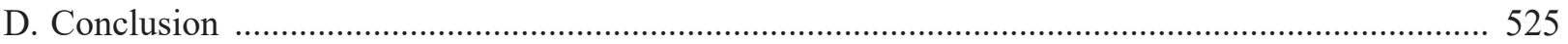

\footnotetext{
Doctoral Dissertation Research Funded by Institute for Research and Community Service, University of Syiah Kuala, 2017.

Correspondence address: insa.ansari@unsyiah.ac.id; muhammad.insa@ui.ac.id
} 


\section{A. Research Background}

Oil and natural gas is a very important need in the development of a nation. ${ }^{1}$ Even oil and natural gas as a non-renewable strategic mining materials, it actually plays a dominant role, both in terms of earning foreign exchange, state revenues for development financing and the fulfillment of domestic energy needs. ${ }^{2}$ Even the level of oil and gas use is often used to measure the welfare of a society. ${ }^{3}$

Utilization of Indonesia's oil and gas even in the period prior to Indonesia Merdeka, only the utilization at that time more for the interests of colonial government. ${ }^{4}$ In the period of Dutch colonial, the role of oil compared to other agricultural products and mining had not been so great. ${ }^{5}$

After the independence of Indonesia, the basic principles of oil and gas control were laid down. ${ }^{6}$ In the preamble of the 1945 Constitution, one of its aims is to promote the common good. ${ }^{7}$ In order to promote the social welfare of all resources used to realize these ideals, including the use of natural resources owned by this archipelago. In addition, Article 33 Paragraph (3) of the 1945 Constitution states that "The earth and the water of natural wealth contained therein are controlled by the state and used for the greatest prosperity of the people." The consequence of that is the Indies Indies Mining Act Mijn Wet), among others, to regulate oil and natural gas mining concessions replaced by new regulations until Pertamina was established (stateowned company operated as executive) in the oil mining sector. ${ }^{9}$

One of the important things in the legislation is related to the position of the state in the oil and gas sector and the role of government in realizing the general welfare. Besides, it is not less important is related to the role of state enterprises (today known as BUMN) in realizing prosperity through public service obligation (obligation of public service obligation) assigned by the government.

Based on the background as described, this research explains and analyzes 2 (two) points, namely: First, how the state position on oil and natural gas in the constitution and the laws and regulations governing the oil and gas sector? Second, how is the role of SOEs as the bearer of public service obligation in the oil and gas sector?

Emil Salim, "Pengembangan Minyak dan Gas Bumi Berwawasan Lingkungan," Speech, Briefing of the State Minister of Population at the Meeting of the $100^{\text {th }}$ Years Anniversary of Oil and Gas Mining Business in Indonesia, Jakarta, 14-17 October 1985. Where in the paper stated: "During the first century, oil and gas mining business has provided great benefits to the development of Indonesia." See: Ibrahim Hasyim, 2005, Siklus Krisis di Sekitar Energi, Proklamasi Publishing House, Jakarta, p. 131. In the book stated as follows, "Oil has been contributing to the continuity of development. He is a foreign exchange earning hero who supports the continuity of our country. However, in addition to the potential wealth, oil also keeps potential problems. It is not possible in the future oil will also contribute to the emergence of various problems in the country."

Supomo M. Atmodjo, et al., "Peranan Kurikulum Dalam Membentuk Tenaga Profesional di Bidang Exploitasi Minyak dan Gas Bumi”, Paper, at the Meeting of the $100^{\text {th }}$ Years Anniversary of Oil and Gas Mining Business in Indonesia, Jakarta, 14-17 October 1985.

Herman Haeruman J.S., "Pengembangan Produksi Minyak dan Gas Bumi Yang Berwawasan Lingkungan", Paper, at the Meeting of the $100^{\text {th }}$ Years Anniversary of Oil and Gas Mining Business in Indonesia, Jakarta, 14-17 October 1985. It's written that, "The level of energy use is often used to measure the welfare of a society. The higher the use of energy the higher the prosperity level of a society. The relationship between national income and energy use appears to be directly proportional. Nevertheless some developed countries such as Scandinavian countries have proven that the same increase in national income can be achieved with lower energy consumption."

Wahjudi Wisaksono and Jaspar Bilal, "Minyak dan Gas Bumi yang Berwawasan Lingkungan", Paper, at the Meeting of the 100"th Years Anniversary of Oil and Gas Mining Business in Indonesia, Jakarta, 14-17 October 1985. It's stated that, "Utilization of oil and natural gas as Indonesia's natural resources during the colonial period is used for the interests of colonizers, to utilize it is not abundant in the interests of the Indonesian nation, both during the Dutch East Indies government and Japan.”

Ibid.

Ibid. It's written that, "Since the proclamation of 17 August 1945 laid the foundation of national government policy, among others, concerning oil and gas business."

Ibid. In the preamble of the 1945 Constitution, the government of the Republic of Indonesia aims to promote the common welfare, to educate the life of the nation, to implement the world order based on independence, eternal peace and social justice.

Article 33 par. (3) the 1945 Constitution of the Republic of Indonesia. See also: A. Zen Umar Purba, "Pengelolaan Lingkungan Dalam Penguasaan Minyak dan Gas Bumi Lepas Pantai Suatu Tinjau Hukum," Paper, at the Meeting of the $100^{\text {th }}$ Years Anniversary of Oil and Gas Mining Business in Indonesia, Jakarta, 14-17 October 1985. It's stated that, "This provision refers not only to the aspect of the status of natural resources, or natural resources in Indonesia, the utilization dimension only. But this formula is reasoned to the broader sense, namely "the greatest prosperity of the people". If we now believe that the purpose of development is the human development itself...".

9 Wahjudi Wisaksono and Jaspar Bilal, Loc. cit. 


\section{B. Research Methods}

The research used in this research is normative law research or literature research. As a normative legal research, this study is based on an analysis of legal norms (law as it's written in the books), or law as it is decided by judge through judicial process). ${ }^{10}$

Where in this study only use secondary data only. ${ }^{11}$ Secondary data in this study include primary legal materials, secondary legal materials and tertiary legal materials. Where the research is done by conducting a positive law inventory as a baseline and fundamental activity to conduct research and study in this research. ${ }^{12}$

Primary legal materials are binding legal materials, comprising basic norms, basic rules, statutory regulations, jurisprudence, and treaties. ${ }^{13}$ Moreover, the primary legal material is a legal material that is autoritative means to have authority. The primary legal material consists of legislation, official records or treatises in the making of legislation and judgmental decisions. ${ }^{14}$

Secondary materials of all publications on law include textbooks, legal dictionaries, legal journals, and comments on court decisions. ${ }^{15}$ Where the secondary law material provides an explanation of the primary legal materials, such as the draft law, the results of research, the work of the law. ${ }^{16}$

\section{Research Results and Analysis}

1. Position of the State in the Field of Oil and Gas

In the 1945 Constitution there are two important provisions relating to oil and gas. ${ }^{17}$ The two provisions are: First, Article 33 paragraph (2) states, "Sectors of production which are important for the country and affect the life of the people shall be under the powers of the State." ${ }^{\prime 18}$ Second, Article 33 Paragraph (3) of the 1945 Constitution states that, "The land, the waters and the natural resources within shall be under the powers of the State and shall be used to the greatest benefit of the people."19

Article 33 paragraph (2) and (3) of the 1945 Constitution is the basis for the state in the management of natural resources or natural resources owned by this nation. This provision is the basis given by the constitution ${ }^{20}$ to the management of natural resources or natural resources. The foundation of this constitution is none other than in order to realize prosperity for the nation. ${ }^{21}$

The provisions contained in Article 33 paragraph (2) and paragraph (3) of the 1945 Constitution have consequences in the laws and regulations governing oil and earth mining. The following will be reviewed 2 (two) important things related to natural resource managers in the form of oil and natural gas, namely:

\section{a. Oil and Gas as an Important Sector and Affect the Public's Life}

As already stated earlier that oil and gas is one of the most important energy resources for Indonesia. So that in Law No. 30 of 2007 on Energy (Law No. 30 of 2007) stated that energy resources controlled by the state. Some of the provisions contained in Law No.

\footnotetext{
Ronal Dworkin, 1977, Legal Research, Spring, Daedalung, p. 250.

Soerjono Soekanto and Sri Mahmudji, 2001, Penelitian Hukum Normatif: Suatu Tinjauan Singkat, Radja Grafindo Persada, Jakarta, p. 14.

Bambang Sunggono, 1997, Metode Penelitian Hukum, Radja Grafindo Persada, Jakarta, p. 81.

Soekanto, et al., 2001, Penelitian Hukum Normatif: Suatu Tinjauan Singkat, Radja Grafindo Persada, Jakarta, p. 13.

Peter Mahmud Marzuki, 2008, Penelitian Hukum, Kencana Prenada Media Group, Jakarta, p. 12.

Ibid., p. 12.

Soerjono Soekanto and Sri Mahmudji, 2001, Penelitian Hukum Normatif: Suatu Tinjauan Singkat, Radja Grafindo Persada, Jakarta, p. 13.

John A Katili, "Re-evaluasi Peta Sumber Daya Energy", Speech, at the Meeting of the $100^{\text {th }}$ Years Anniversary of Oil and Gas Mining Business in Indonesia, Jakarta, 14-17 October 1985. It's stated that, "It is undeniable that hydrocarbon resources as one of the most important resources for Indonesia and are a major resource for state finance, so that detailed knowledge of hydrocarbon reserves is a "condition cine qua non" for nation building."

8 Article 33 par. (2) the 1945 Constitution of the Republic of Indonesia.

9 Article 33 par. (3) the 1945 Constitution of the Republic of Indonesia. See: A. Zen Umar Purba, Loc. cit.

20 Jimly Asshiddiqie, 2006, Konstitusi dan Konstitusionalisme Indonesia, Konstitusi Press, Jakarta, p. 35. He said that, “The Constitution is the basic law that is used as the guidance in the administration of a country. The Constitution may be a basic written law commonly referred to as the Constitution, and may not be written. Not all countries have a written constitution or the Constitution."

21 Editorial Team of Vice Chairman of the Constitutional Court of the Republic of Indonesia, 2008, Konstitusi Sebagai Rumah Bangsa: Pemikiran Dr. Harjono, S.H., M.C.L Wakil Ketua Mahkamah Konstitusi, Secretary General of the Constitutional Court of the Republic of Indonesia, Jakarta, p. 16.
} 
30 of 2007 relating to the state control over the field of energy resources, among others are: First, consideration of consideration a. 30 of 2007 stating: “..that energy resources as natural resources as mandated in Article 33 of the 1945 Constitution of the State of the Republic of Indonesia is controlled by the state and used for the greatest prosperity of the people". ${ }^{22}$ Second, Article 4 paragraph (1) of Law No. 30 of 2007 which states: "Fossil energy resources, geothermal, largescale hydro, and nuclear energy sources controlled by the state and utilized for the greatest prosperity of the people." ${ }^{23}$ Third, the General Explanation of Law No. 30 of 2007 where stated: "Energy resources as natural wealth is a gift of God Almighty to the people and nation of Indonesia. In addition, energy resources are strategic natural resources and very important for the livelihood of the people, especially in the improvement of economic activities, employment opportunities, and national resilience of energy resources must be controlled by the state and used for the greatest prosperity of the people as mandated in Article 33 of the 1945 Constitution of the State of the Republic of Indonesia." ${ }^{24}$

So that in Law No. 30 of 2007, the government has a number of obligations, among them are: First, the government is obliged to provide reserves of energy buffer, to ensure national energy security. ${ }^{25}$ Secondly, the government is obliged to tackle the state of crisis and energy emergency, as stated: (1) The energy crisis is a condition of energy shortage. (2) Emergency energy is a condition of disruption of energy supply due to the breakdown of facilities from energy infrastructure. (3) In the case of energy and energy emergency crises, as referred to in paragraphs (1) and (2), it is expected that the disruption of government functions, social life of society, and/or economic activity, the Government shall carry out necessary countermeasures. ${ }^{26}$ Third, local governments provide subsidy for disadvantaged groups. The obligation of the government and local governments to provide subsidy for these poor societies is one of the public service obligations undertaken by the government in the setor of energy. Fourth, the government must increase the utilization of new energy and renewable energy.

Besides, based on Law No. 30 of 2007 , the government acts as a supervisor of energy resources, source of energy, and energy, ${ }^{27}$ and also supervises energy resources, source of energy, and energy. ${ }^{28}$

In Law Number 22 of 2001 on Oil and Natural Gas (Law No. 22 of 2001) stated that oil and natural gas is an important production branch for the state and affect the livelihood of the people. Where in the general explanation is expressed as quoted below:

The 1945 Constitution Article 33 paragraph (2) and paragraph (3) affirms that the production branches that are important for the state and which affect the livelihood of the

22 Preamble, Considering letter a Law Number 30 of 2007 on Energy (State Gazette of the Republic of Indonesia Year 2007 Number 96, Supplement to State Gazette of the Republic of Indonesia Number 4746).

23 Article 4 par. (1) Law Number 30 of 2007 on Energy (State Gazette of the Republic of Indonesia Year 2007 Number 96, Supplement to State Gazette of the Republic of Indonesia Number 4746).

24 First paragraph of General Eludication of Law Number 30 of 2007 on Energy (State Gazette of the Republic of Indonesia Year 2007 Number 96, Supplement to State Gazette of the Republic of Indonesia Number 4746).

25 Article 5 par. (1) Law Number 30 of 2007 on Energy (State Gazette of the Republic of Indonesia Year 2007 Number 96, Supplement to State Gazette of the Republic of Indonesia Number 4746).

26 Article 6 Law Number 30 of 2007 on Energy (State Gazette of the Republic of Indonesia Year 2007 Number 96, Supplement to State Gazette of the Republic of Indonesia Number 4746).

27 Article 27 Law Number 30 of 2007 on Energy (State Gazette of the Republic of Indonesia Year 2007 Number 96, Supplement to State Gazette of the Republic of Indonesia Number 4746).

28 Article 28 Law Number 30 of 2007 on Energy (State Gazette of the Republic of Indonesia Year 2007 Number 96, Supplement to State Gazette of the Republic of Indonesia Number 4746). 
people are controlled by the state. Similarly earth and water and natural resources contained therein are controlled by the state and used for the greatest prosperity and welfare of the people. Considering that oil and natural gas is a non-renewable strategic natural resources controlled by the state and is a vital commodity that plays an important role in the provision of industrial raw materials, the fulfillment of domestic energy needs, and an important source of state income, the management needs to be done optimally can be utilized for the greatest prosperity and prosperity of the people. ${ }^{29}$

Oil and gas mining is one of the important production branches previously mentioned in Government Regulation in Lieu of Law No. 44 of 1960 on Oil and Gas Mining (Government Regulation in Lieu of Law No. 44 of 1960). Where in the Consideration letter b is declared, "that oil and gas production constitute production branches which are important for the state and affect the livelihood of the public, whether directly or indirectly." 30

Based on Law No. 30 of 2007, Law No.22 of 2001, and Government Regulation in Lieu of Law No. 44 of 1960 as described above shows oil and natural gas as an important production branch and controls the lives of many people. The definition of the right to control the state itself has a higher position than just ownership, namely sovereingnity in public law, while ownership is in the hands of all Indonesian people. ${ }^{31}$ Even in some decisions of the Constitutional
Court the right to control the state has been translated into a number of functions, namely: policies and actions of management, management, and supervision aimed at the greatest prosperity of the people. These decisions relate to judicial review of the management of oil and gas, water resources, electricity, coal mining, and shipping.

\section{b. State Control over Oil and Gas}

In Law no. 22 of 2001 regulates state control of the oil and gas sector. Several provisions in the law which mention the control of the state are as follows: First, consideration of the letter b of Law No. 22 of 2001 stating "that oil and natural gas is a non-renewable strategic natural resources dominated by the state and is a vital commodity that controls the livelihood of the people and has an important role in the national economy so that its management must be able to maximally provide prosperity and welfare of the people. ${ }^{32}$ Second, Article 4 paragraph (1) of Law No. 22 of 2001 stating that oil and natural gas as a non-renewable strategic natural resource contained within the Indonesian Legal Mining Territory is a national asset controlled by the state. ${ }^{33}$ Third, General Explanation on Law No. 22 of 2001, whereas stated, "The 1945 Constitution, Article 33 paragraph (2) and paragraph (3), affirm that the important production branches for the state and which control the livelihood of the people are controlled by the state ... Given oil and natural gas is a non-renewable strategic natural resource that is controlled by the state and is a vital commodity that plays an important role ...." ${ }^{34}$

29 General Eludication of Law Number 22 of 2001 on Oil and GasMinyak dan Gas Bumi (State Gazette of the Republic of Indonesia Year 2001 Number 136, Supplement to State Gazette of the Republic of Indonesia Number 4152).

30 Preamble, Considering letter b Government Regulation in Lieu of Law No. 44 of 1960 on Oil and Gas Mining (State Gazette of the Republic of Indonesia Year 1960 Number 33, Supplement to State Gazette of the Republic of Indonesia Number 2070).

Teddy Anggoro, 2016, Monopoli Alamiah Badan Usaha Milik Negara, Herya Media, Bogor, p. 366.

32 Preamble, Considering letter b Law Number 22 of 2001 on Oil and Gas (State Gazette of the Republic of Indonesia Year 2001 Number 136, Supplement to State Gazette of the Republic of Indonesia Number 4152).

33 Art. 4 par. (1) Law Number 22 of 2001 on Oil and Gas (State Gazette of the Republic of Indonesia Year 2001 Number 136, Supplement to State Gazette of the Republic of Indonesia Number 4152).

34 General Eludication of Law Number 22 of 2001 on Oil and Gas (State Gazette of the Republic of Indonesia Year 2001 Number 136, Supplement to State Gazette of the Republic of Indonesia Number 4152). 
As a follow up of state control over oil and gas, the Government through the Law No. 22 of 2001 is granted a number of obligations by the State in the form of Public Service Obligation (PSO). One of the obligations of public services carried by the government in the oil and gas sector in Law No. 22 of 2001 is as quoted as follows: "The Government shall ensure the availability and smooth distribution of Fuel Oil which is a vital commodity and affect the livelihood of the people throughout the territory of the Unitary State of the Republic of Indonesia." ${ }^{35}$ In the explanation of the obligations of the government is stated as quoted below: "The Government is obliged to keep the need for Fuel Oil throughout the country, including remote areas, to be fulfilled and also to keep a sufficient national reserve available for a certain period of time." 36

In short, the public service obligations undertaken by the government are linked to the state's control of the oil and gas sector and are an affair of the production branches that are important to the State and which affect the livelihood of the masses dominated by the State. This is a constitutional mandate that must be assumed by the government as the state organizer.

Earlier, in Law No. 8 of 1971 on the State Oil and Gas Mining Company and its amendments, last amended by Law Number 10 of 1974 (State Gazette Year 1974 Number 3045) does not mention the state's control over oil and natural gas. As a result, Law No. 8 of 1971 does not regulate the public service obligation that must be carried by the government in the oil and gas sector. However, in Law No. 8 of 1971 only regulates supervision by the government, which includes supervision of production, safety supervision and other activities in oil and gas mining concerning the public interest. ${ }^{37}$

Moreover, Law Number 15 of 1962 concerning Stipulation of Government Regulation in Lieu of Law No. 2 of 1962 concerning Obligation of Oil Company to Meet Domestic Demand (Law No. 15 of 1962) does not provide regulation over state control over oil and natural gas. In Law No. 15 of 1962 also does not set the obligation of public services that must be carried by the government in the oil and gas sector.

However, state control over oil and natural gas was previous regulated in Government Regulation in Lieu of Law No. 44 of 1960 on Oil and Gas Mining, that, "All the materials of excavation of oil and natural gas in the territory of mining law of Indonesia is a national asset controlled by the State." 38

It's interesting that, Government Regulation in Lieu of Law No. 44 of 1960, although the control of the state is firmly regulated therein, but the obligation of public service which must be carried by the government is not regulated at all in the perpu intended. In Perpu No.44 of 1960, the government only acts in the administration and supervision of the works and the implementation of the oil and gas mining business, which is the authority of departments whose field of duty covers oil and gas mining. ${ }^{39}$

In connection with Government

\footnotetext{
35 Art. 8 par. (2) Law Number 22 of 2001 on Oil and Gas (State Gazette of the Republic of Indonesia Year 2001 Number 136, Supplement to State Gazette of the Republic of Indonesia Number 4152).

36 Eludication of Art. 8 par. (2) Law Number 22 of 2001 on Oil and Gas (State Gazette of the Republic of Indonesia Year 2001 Number 136, Supplement to State Gazette of the Republic of Indonesia Number 4152).

37 Art. 2 par. (2) Law Number 8 of 1971 on Oil and Gas Mining Company (State Gazette of the Republic of Indonesia Year 1971 Number 76, Supplement to State Gazette of the Republic of Indonesia Number 2971).

38 Art. 2 Government Regulation in Lieu of Law No. 44 of 1960 on Oil and Gas Mining (State Gazette of the Republic of Indonesia Year 1960 Number 33, Supplement to State Gazette of the Republic of Indonesia Number 2070).

39 Art. 16 Government Regulation in Lieu of Law No. 44 of 1960 on Oil and Gas Mining (State Gazette of the Republic of Indonesia Year 1960 Number 33, Supplement to State Gazette of the Republic of Indonesia Number 2070).
} 
Regulation in Lieu of Law No. 44 of 1960, at that time Anderson G Bartlett III, et al., in his book Pertamina: Indonesian National Oil writes:

Law No. 44 of 1960 clearly signified the beginning of new era in Indonesian oil. It is, sometimes, stated to be a natural corollary to Article 33, Paragraphs (2) and (3) of the Constitution of 1945, which are cited in the Law's preface. The pertinent Constitutional provisions are:

Sec. 2. Branches of production which are important to the State and which affect the life of most people, shall be controlled by the Stated.

Sec. 3. Land and water and the natural riches therein shall be controlled by the State and shall be exploited for the greates welfare of the people. ${ }^{40}$

In short the state's control over oil and natural gas in the prevailing laws and regulations is different, but still in the position of state control. The differences in state tenure arrangements influence the role of government, particularly on public service obligation.

\section{Public Service Obligation in the Sector of Oil and Gas by State-Owned Enterprise}

The obligation of public services is basically the obligation that must be done by the government as the organizer of state power. The 1945 Constitution expressly states that "The State is responsible for the provision of health service facilities and appropriate public service facilities." ${ }^{41}$ The provision is the basis for the government in carrying out public service obligations in the oil and gas sector.

In Law No. 22 of 2001, relating to SOEs and public service obligations in the oil and gas sector is vaguely stated that at the time this law is in effect Pertamina shall continue to undertake the task of supply and service of Fuel Oil for domestic purposes until a period of time maximum of 4 (four) years. ${ }^{42}$

In addition, in Law No. 22 of 2001 does not regulate public service obligation of state-owned companies in the oil and gas sector. However, in relation to state-owned enterprises engaged in the oil and gas business sector in this law is only declared, "State-owned companies other than Pertamina which has oil and gas business activities, among others, is PT. Perusahaan Gas Negara (Persero) established under Government Regulation No. 37 of 1994." ${ }^{\prime 43}$

Previously in Law No. 8 of 1971 jo. Law No. 10 of 1974 on the Amendment of Article 19 paragraph (1) of Law Number 8 of 1971 is the legal basis for the establishment of the State Company of Pertamina, but it does not regulate the obligation of public services that must be carried by the State Company of Pertamina. It's just that in Law No. 8 of 1971 stated that the State Company of Pertamina is an amalgamation of the Indonesian Petroleum Mining Company, as stipulated in Government Regulation No. 3 of 1961 and the National Petroleum Mining Company, as stipulated in Government Regulation No. 198 of $1961 .{ }^{44}$ Even in the book of Pertamina: Indonesian National Oil is mentioned as quoted below:

Indonesia is one of the few countries which operates a fully integrated oil company completely and solely under its own national management. From drilling rigs to computers, from tankers to helicopters, refineries to service stations, Pertamina's divisions and operations are fully Indonesian owned and operated.

\footnotetext{
Anderson G. Bartlett III, et.al., 1972, Pertamina Indonesia National Oil, American Ltd., Jakarta, p. 183.

Article 34 par. (4) of the 1945 Constitution of the Republic of Indonesia.

Article 62 Law Number 22 of 2001 on Oil and Gas (State Gazette of the Republic of Indonesia Year 2001 Number 136, Supplement to State Gazette of the Republic of Indonesia Number 4152).

43 Eludication of Art. 64 letter a Law Number 22 of 2001 on Oil and Gas (State Gazette of the Republic of Indonesia Year 2001 Number 136, Supplement to State Gazette of the Republic of Indonesia Number 4152).

44 Article 1 par. (2) Government Regulation Number 27 of 1968 on Establishment of State Oil and Gas Mining Company (State Gazette of the Republic of Indonesia Year 1968 Number 44).
} 
Pertamina's exploration and production rigs drill onshore locations throughout the archipelago. Pertamina's own production. ${ }^{45}$

Meanwhile, the purpose of establishing PN Pertamina based on the law is to build and implement oil and gas business in the widest sense for the greatest prosperity of the People and the State and create National Resilience. ${ }^{46}$ The business field of State Company of Pertamina is a company engaged in the field of oil and gas business which includes exploration, exploitation, purification and processing, transportation and sales. ${ }^{47}$ Even in the law it is stated that State Company of Pertamina is granted a Mining Authority whose territorial boundaries and conditions are stipulated by the President on the proposal of the Minister as long as the oil and gas mining. ${ }^{48}$

In Law No. 8 of 1971 also regulated the task of State Company of Pertamina. Where in the Law is stated "Company duties are: a. carrying out oil and natural gas exploitation by obtaining maximum results for the prosperity of the People and the State; b. provide and serve the needs of domestic oil and gas fuels whose implementation is regulated by a Government Regulation." ${ }^{49}$

Previously, in Government Regulation No. 27 of 1968 on the Establishment of State Companies of Oil and Gas Mining, the Company's objectives and business fields were determined. The purpose of the company is a unity of production that helped build the National Economy based on Pancasila with a way to generate profits both in the form of foreign exchange and rupiah for the State for the prosperity and welfare of the people. ${ }^{50}$ While the company's business field is engaged in exploration activities, exploitation, processing, purification of transportation and marketing of minerals of mining oil and gas. ${ }^{51}$

Then, in Law No. 15 of 1962 there is a stipulation that all oil companies in Indonesia are required to participate in meeting domestic demand for petroleum processing products. ${ }^{52}$ The provisions contained in this law are not only directed to State Company of Pertamina, but are addressed to all oil mining companies.

Furthermore, in Government Regulation in Lieu of Law No. 44 of 1960 does not regulate the public service obligation of the oil and natural gas sector to SOEs. Only in the Perppu confirms that the oil and gas mining business is carried out by the State Enterprise solely. ${ }^{53}$ Even the oil and gas mining concession is granted to state companies to carry out oil and gas mining business. ${ }^{54}$

However, in the development, especially since the birth of Law Number 19 of 2003 on State Owned Enterprises (Law No. 19 of 2003), states: "The government may give special assignment to SOEs to perform the function of public benefit by maintaining the intention and the purpose of SOE activities." Even in his explanation mentioned,

45 Anderson G. Bartlett III, et.al., 1972, Pertamina Indonesia National Oil, American Ltd., Jakarta, p. 2.

46 Article 5 Law Number 8 of 1971 on Oil and Gas Mining Company (State Gazette of the Republic of Indonesia Year 1971 Number 76, Supplement to State Gazette of the Republic of Indonesia Number 2971).

47 Article 6 par. (1) Law Number 8 of 1971 on Oil and Gas Mining Company (State Gazette of the Republic of Indonesia Year 1971 Number 76 , Supplement to State Gazette of the Republic of Indonesia Number 2971).

48 Article 11 Law Number 8 of 1971 on Oil and Gas Mining Company (State Gazette of the Republic of Indonesia Year 1971 Number 76 , Supplement to State Gazette of the Republic of Indonesia Number 2971).

49 Article 13 Law Number 8 of 1971 on Oil and Gas Mining Company (State Gazette of the Republic of Indonesia Year 1971 Number 76 , Supplement to State Gazette of the Republic of Indonesia Number 2971).

50 Article 5 par. (1) Government Regulation Number 27 of 1968 on Establishment of State Oil and Gas Mining Company (State Gazette of the Republic of Indonesia Year 1968 Number 44).

51 Article 5 par. (3) Government Regulation Number 27 of 1968 on Establishment of State Oil and Gas Mining Company (State Gazette of the Republic of Indonesia Year 1968 Number 44).

52 Article 1 Law Number 15 of 1962 on Stipulation of Government Regulation in Lieu of Law No. 2 of 1962 concerning Obligation of Oil Company to Meet Domestic Demand (State Gazette of the Republic of Indonesia Year 1962 Number 80, Supplement to State Gazette of the Republic of Indonesia Number 5167).

53 Art. 3 par. (2) Government Regulation in Lieu of Law No. 44 of 1960 on Oil and Gas Mining (State Gazette of the Republic of Indonesia Year 1960 Number 33, Supplement to State Gazette of the Republic of Indonesia Number 2070).

54 Art. 1 letter a Government Regulation in Lieu of Law No. 44 of 1960 on Oil and Gas Mining (State Gazette of the Republic of Indonesia Year 1960 Number 33, Supplement to State Gazette of the Republic of Indonesia Number 2070). 
Although SOEs are established with the intent and purpose to pursue profit, it is possible for things that are urgent, SOEs are given special assignment by the government. If the assignment is not financially feasible, the government should provide compensation for all expenses incurred by the BUMN including the expected margin. ${ }^{55}$

In line with the provisions of Article 66 paragraph (1) of Law No. 19 Ion2003, PT. Pertamina (Persero) is assigned by the government for the provision and distribution of certain fuel, the supply and distribution of 3 (three)-kilograms liquefied petroleum gas (LPG). The value of public service obligation (obligation of public service obligation) which is charged to PT. Pertamina (Persero) can be seen in the following diagram:

\section{Diagram 1.}

The Value of Public Service Obligations carried out by PT. Pertamina (Persero)

\section{(in rupiah and billion)}

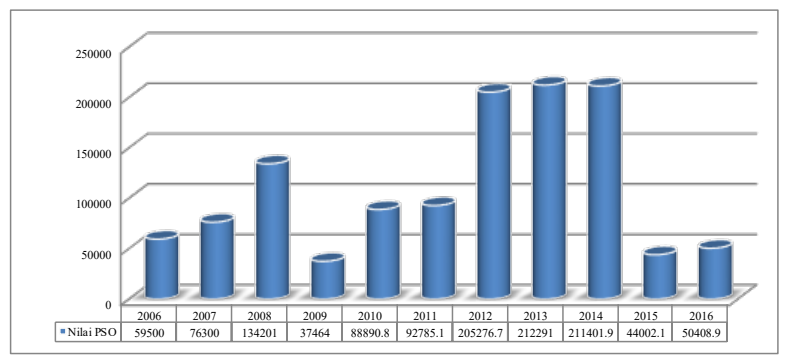

Source: Data from Keasdepan Data Team and Information Technology of Ministry of BUMN is processed from 2006 until 2016 projection.
The details of the value of public service obligation carried by PT. Pertamina (Persero) is in 2006 amounted to 59,500 billion rupiahs, in 2007 amounted to 76,300 billion rupiahs, in 2008 of 134,201 billion rupiahs, in 2009 amounted to 37,464 billion rupiahs, in 2010 amounted to $88,890.8$ billion rupiahs, in 2011 amounted to $92,785.1$ billion rupiah, in 2012 amounted to 205,276.7 billion rupiahs, in 2013 of 212,291 billion rupiahs, ${ }^{56} 2014$ of 211,401.9 billion rupiahs, ${ }^{57}$ in 2015 amounting to $44,002.1$ billion rupiahs and projected for 2016 of 50,408.9 billion rupiahs.

Public service obligation by PT. Pertamina (Persero) in the status of Limited Liability Company is not a Public Company (Perum) there is a contradiction of corporation law. Among them are: First, based on the notion of SOE entities distinguished between entities of SOE that bear public utility and entities of SOE that fosters profit (profit oriented). This can be reviewed on the basis of the company's understanding of the company and the public company. Where a company is a state-owned enterprise which is a limited liability company whose capital is divided into shares wholly or at least $51 \%$ (fifty one percent) of its shares are owned by the Republic of Indonesia whose main purpose is to pursue profits, ${ }^{58}$ while a public company is a state-owned enterprise wholly owned by the state and is not divided into shares, which aims for the general benefit of providing high quality goods and/or services while pursuing profits based on company management principles. ${ }^{59}$

\footnotetext{
Article 66 par. (1) Law Number 19 of 2003 on State Owned Enterprise (State Gazette of the Republic of Indonesia Year 2003 Number 70 , Supplement to State Gazette of the Republic of Indonesia Number 4297).

56 Pertamina, "Pertamina Tegaskan Tidak Ada Penggelembungan Klaim Subsidi", http://www.pertamina.com/news-room/siaran-pers/pertaminategaskan-tidak-ada-penggelembungan-klaim-subsidi/, accessed 2 November 2014. It's said that, "In the distribution of fuel and LPG subsidy, Pertamina first bail all the procurement of fuel and LPG, then filed a claim to the Government on the volume that has been distributed. The volume is then verified by BPH and the Ministry of Finance as a basis for payment of $95 \%$ of the total volume billed on a monthly basis. The remaining bills will be paid after an audit by BPK. Meanwhile, the status up to 27 September 2013, for the realization of subsidized fuel distribution and LPG $3 \mathrm{~kg}$ total of Pertamina's receivables to the Government reached Rp39.73 trillion."

57 Pertamina, "Pertamina Terima Mandat BBM PSO 2014", http://www.pertamina.com/news-room/seputar-energi/pertamina-terima-mandatbbm-pso-2014/?altemplate=print, accessed 2 November 2014. It states that, "Pertamina has become the main business entity that gains the trust of the Downstream Oil and Gas Regulatory Agency (BPH Migas) to provide and distribute certain types of fuel oil by 2014."

58 Art. 1 point 2 of Law Number 19 of 2003 on State Owned Enterprise (State Gazette of the Republic of Indonesia Year 2003 Number 70 , Supplement to State Gazette of the Republic of Indonesia Number 4297). The provision of Art. 1 point 2 said that, "The Company, hereinafter referred to as Persero, is a state-owned enterprise which is a limited liability company whose capital is divided into shares wholly or at least $51 \%$ (fifty one percent) of whose shares are owned by the Republic of Indonesia whose main purpose is to pursue profit."

59 Art. 1 point 4 Law Number 19 of 2003 on State Owned Enterprise (State Gazette of the Republic of Indonesia Year 2003 Number 70 , Supplement to State Gazette of the Republic of Indonesia Number 4297). It states that, "Public Company, hereinafter referred to as Perum, is a State-Owned Enterprise wholly owned by the state and is not divided into shares, which is intended for general benefit in the form of providing goods and/or services of high quality and pursuing profit based on company management principles."
} 
Second, based on the intent and purpose of BUMN entities have different intent and purpose between company and public company. Where the company itself is established with the intent and purpose to provide goods and/or services of high quality and strong competitive and pursue profit in order to increase the value of the company ${ }^{60}$ while the public company was established with the intent and purpose for public benefit in the form of provision of goods and/or service quality at an affordable price by the community based on sound corporate management principles. ${ }^{61}$ Third, in the elucidation of article by article of the State Owned Company Law there is a provision that annuls the definition, intent, and purpose of the company. ${ }^{62}$ Where the government can provide special assignment to the company's corporate entity that in fact based on the understanding, intent, and purpose is none other to a form of profit-oriented.

In addition to the matters as aforementioned, in relation to public service obligation has been directed and directed as the domein of his public company. This can be seen at least in the statement of the Minister of State-Owned Enterprises representing the government in the discussion of State-Owned Entreprise Bill, which is stated explicitly:

[...] the nature of SOEs business is to cultivate profits and carry out general benefits, SOEs are simplified into two forms, namely the Coorporation (PERSERO) which aims to foster profits and are fully subject to the provisions of Law of Limited Liability Company and Public Corporation (PERUM) established by the government to carry out business as the implementation of obligations government to provide certain goods and services to meet the needs of the community. For PERUM's form of business, although its existence is to carry out general benefit, however, as a business entity is strived to remain self-sufficient and therefore PERUM must earn a profit in order to live sustainably. ${ }^{63}$

Moving on to the statement of the Minister of State-Owned Enterprises representing the government in the discussion of the State-Owned Enterprises Bill and the understanding of the entity of the general company and the company, the intent and purpose of the entity of the public company and the company, in this case it is understood that the public service obligation basically more directed to be held by public companies while the company is typically a profit-oriented business entity.

\section{Conclusion}

State Owned Enterprises (SOEs) and Public Service Obligations in the Oil and Gas Sector are as follows: First, the provisions of Article 33 paragraph (2) and paragraph (3) of the 1945 Constitution are the basic rules of governing state control over natural resources in the form of oil and gas. Second, the provisions of Article 33 paragraph (2) and paragraph (3) of the 1945 Constitution contain consequences on Oil and Gas as a branch of Production of Important and Mastery of People's Lives and State Control of Oil and Gas. Third, the public service obligation carried out by the SOEs is not only laid on the Public Corporation (Perum) but also entity of Limited Liability Company.

60 Article 12 Law Number 19 of 2003 on State Owned Enterprise (State Gazette of the Republic of Indonesia Year 2003 Number 70 , Supplement to State Gazette of the Republic of Indonesia Number 4297).

61 Article 36 Law Number 19 of 2003 on State Owned Enterprise (State Gazette of the Republic of Indonesia Year 2003 Number 70 , Supplement to State Gazette of the Republic of Indonesia Number 4297).

62 Eludication of Art. 66 par. (1) Law Number 19 of 2003 on State Owned Enterprise (State Gazette of the Republic of Indonesia Year 2003 Number 70, Supplement to State Gazette of the Republic of Indonesia Number 4297). It states that, "Although SOEs are established with the intent and purpose to pursue profit, it is possible for things that are urgent, SOEs are given special assignment by the government. If the special assignment is not fisically assessed by the study, the government should provide compensation for all expenses incurred by the BUMN including the expected margin."

63 The Ministry of State Owned Enterprises of the Republic of Indonesia, 2009, Keterangan Menteri Badan Usaha Milik Negara Mewakili Pemerintah Mengenai Rancangan Undang-Undang tentang Badan Usaha Milik Negara, The Ministry of State Owned Enterprises of the Republic of Indonesia, Jakarta, p. 9. 


\section{REFERENCES}

\section{A. Book}

Anggoro, Teddy, 2016, Monopoli Alamiah Badan Usaha Milik Negara, Herya Media, Bogor.

Anonim, 1970, Industri Minjak Bumi, PT. Stanvac Indonesia, Jakarta.

Dworkin, Ronal, 1977, Legal Research, Spring, Daedalung.

G. Bartlett III, Anderson, et.al., 1972, Pertamina: Indonesia National Oil, American Ltd, Jakarta.

Hasyim, Ibrahim, 2005, Siklus Krisis di Sekitar Energi, Proklamasi Publishing House, Jakarta.

Kementerian Badan Usaha Milik Negara, 2002, Keterangan Menteri Badan Usaha Milik Negara mewakili pemerintah mengenai Rancangan Undang-Undang tentang Badan Usaha Milik Negara, Kementerian BUMN, Jakarta.

Marzuki, Peter Mahmud, 2008, Penelitian Hukum, Kencana Prenada Media Group, Jakarta.

Soekanto, Soerjono dan Sri Mahmudji, 2001, Penelitian Hukum Normatif: Suatu Tinjauan Singkat, Radja Grafindo Persada, Jakarta.

Sunggono, Bambang, 1997, Metode Penelitian Hukum, Radja Grafindo Persada, Jakarta.

\section{B. Paper/Speech}

Atmodjo, Supomo M., Karnata Arjani, Arifin, "Peranan Kurikulum Dalam Membentuk Tenaga Profesional di Bidang Exploitasi Minyak dan Gas Bumi”, Paper, Briefing of the State Minister of Population at the Meeting of the $100^{\text {th }}$ Years Anniversary of Oil and Gas Mining Business in Indonesia, Jakarta, 14-17 October 1985.

Haeruman JS, Herman, "Pengembangan Produksi Minyak dan Gas Bumi Yang Berwawasan Lingkungan", Paper, Briefing of the State Minister of Population at the Meeting of the $100^{\text {th }}$ Years Anniversary of Oil and Gas Mining Business in Indonesia, Jakarta, 14-17
October 1985.

Katili, John A., "Re-evaluasi Peta Sumber Daya Energy", Speech, Briefing of the State Minister of Population at the Meeting of the $100^{\text {th }}$ Years Anniversary of Oil and Gas Mining Business in Indonesia, Jakarta, 14-17 October 1985.

Purba, A. Zen Umar, "Pengelolaan Lingkungan dalam Penguasaan Minyak dan Gas Bumi Lepas Pantai Suatu Tinjau Hukum”, Paper, Briefing of the State Minister of Population at the Meeting of the $100^{\text {th }}$ Years Anniversary of Oil and Gas Mining Business in Indonesia, Jakarta, 14-17 October 1985.

Salim, Emil, "Pengembangan Minyak dan Gas Bumi Berwawasan Lingkungan", Speech, Briefing of the State Minister of Population at the Meeting of the $100^{\text {th }}$ Years Anniversary of Oil and Gas Mining Business in Indonesia, Jakarta, 14-17 October 1985.

Wisaksono, Wahjudi dan Jaspar Bilal, "Minyak dan Gas Bumi yang Berwawasan Lingkungan," Paper, Briefing of the State Minister of Population at the Meeting of the $100^{\text {th }}$ Years Anniversary of Oil and Gas Mining Business in Indonesia, Jakarta, 14-17 October 1985.

\section{Internet Articles}

Anonym, "Pertamina Rugi Saat Mendistribusikan BBM PSO", $\quad$ http://www.wartajakarta. com/berita-5644-pertamina-rugi-saatmendistribusikan-bbm-pso.html, accessed on 19 February 2016.

Pertamina, "Distribusi Domestik", http://www. pertamina.com/company-profile/jaringan/ distribusi-domestik/, accessed on 19 February 2016.

"Pertamina Tegaskan Tidak Ada Penggelembungan Klaim Subsidi”, http:// www.pertamina.com/en/news-room/energyupdate/pertamina-tegaskan-tidak-adapenggelembungan-klaim-subsidi/, accessed 
on 2 November 2014.

, "Pertamina Terima Mandat BBM PSO

2014", http://www.pertamina.com/news$\mathrm{room} / \mathrm{seputar-energi/pertamina-terima-}$ mandat-bbm-pso-2014/? alttemplate $=$ print, accessed on 2 November 2014.

\section{Government Regulations}

The 1945 Constitution of the Republic of Indonesia. Law Number 30 of 2007 on Energy (State Gazette of the Republic of Indonesia Year 2007 Number 96, Supplement to State Gazette of the Republic of Indonesia Number 4746).

Law Number 19 of 2003 on State Owned Enterprise (State Gazette of the Republic of Indonesia Year 2003 Number 70, Supplement to State Gazette of the Republic of Indonesia Number 4297)

Law Number 22 of 2001 on Oil and Gas (State Gazette of the Republic of Indonesia Year 2001 Number 136, Supplement to State Gazette of the Republic of Indonesia Number 4152).
Law Number 8 of 1971 on Oil and Gas Mining Company (State Gazette of the Republic of Indonesia Year 1971 Number 76, Supplement to State Gazette of the Republic of Indonesia Number 2971).

Law Number 15 of 1962 on Stipulation of Government Regulation in Lieu of Law No. 2 of 1962 concerning Obligation of Oil Company to Meet Domestic Demand (State Gazette of the Republic of Indonesia Year 1962 Number 80, Supplement to State Gazette of the Republic of Indonesia Number 5246).

Government Regulation in Lieu of Law Number 44 on 1960 on Oil and Gas Mining (State Gazette of the Republic of Indonesia Year 1960 Number 133, Supplement to State Gazette of the Republic of Indonesia Number 2070).

Government Regulation Number 27 of 1968 on Establishment of State Oil and Gas Mining Company (State Gazette of the Republic of Indonesia Year 1968 Number 44). 